\title{
COMMENTS
}

\section{Brady v. Maryland and the Prosecutor's Duty to Disclose}

The successful operation of the adversary system as a fact-finding device depends on the capacity of each adversary to present evidence favorable to his case and to rebut the evidence of his opponent. In criminal cases, perhaps the most significant disparity between the government's capacity to prosecute and the defendant's capacity to defend derives from the government's vastly superior ability to discover information concerning the alleged crime, to conduct investigations that the defense, in most cases at least, has neither the resources nor the investigative tools to duplicate. ${ }^{1}$ It might be possible to reduce this disparity by providing public defender programs with the resources necessary to locate evidence favorable to the accused. A more efficient remedy, however, since it does not involve costly duplication of investigative efforts, is to place the results of government investigations in the hands of the defense.

In Brady v. Maryland, ${ }^{2}$ the Supreme Court held that the criminal defendant has a constitutional right of access to some of the information in the prosecutor's files. The decision left open a number of questions concerning the nature and extent of this right: whether the defense must request the information; at what point in the criminal process the information must be disclosed; and what constitutes suppression. Most importantly perhaps, the Brady decision failed to define the standard to be used in deciding what evidence must be disclosed to the defense or to deal with the problem of enforcing the duty that it imposed on prosecutors. This comment examines the cases that have followed, interpreted, and expanded the rule announced in Brady and examines their responses to these questions. It concludes that the courts have, on the whole, been too much concerned with attempting to determine whether the suppressed evidence would have changed the outcome of the trial, and too little with the central inquiry required by Brady's rationale: whether the defendant has been accorded a fair trial

1 Brennan, J., The Criminal Prosecution: Sporting Event or Quest for Truth, 1963 WAsH. U.L.Q. 279, 286; Goldstein, The State and the Accused: Balance of Advantage in Criminal Procedure, 69 YALE L.J. 1149, 1172-98 (1960).

2373 U.S. 83 (1963). 
under the due process standard. It suggests that in light of both the fair trial rationale of Brady and the state interests involved in our criminal justice system, the prosecutor's entire file should, except in special cases, be open to defense inspection.

\section{THE Brady RuLE}

The origin of the prosecutor's duty to disclose evidence favorable to the defense is usually traced to Mooney $v$. Holohan, ${ }^{3}$ in which a radical labor leader convicted of first degree murder applied for a writ of habeas corpus, claiming that he had been convicted through the use of manufactured physical evidence and testimony that the prosecutor knew to be fraudulent. ${ }^{4}$ The Supreme Court, in affirming the denial of the writ on procedural grounds, found in dicta that the alleged prosecutorial misconduct was inconsistent with the concept of a fair trial and constituted a denial of due process. ${ }^{5}$ Seven years later, in Pyle $v$. Kansas, 6 the Court reaffirmed and broadened the principle it had expressed in Mooney, proscribing the knowing use of perjured testimony and the "deliberate suppression" of evidence favorable to the accused. In Pyle, as in Mooney, the Court reasoned that the prosecutor's misconduct had deprived the defendant of his constitutional right to a fair trial and thus rendered his conviction void. In two subsequent cases, the Court extended its holding in Pyle, ruling that defendants had been denied due process where the perjury ${ }^{7}$ of a witness had been known to

3294 U.S. 103 (1935).

4 After an extensive review of the evidence in the Mooney trial and the facts surrounding the case, the report of the Section on Lawless Enforcement of the Law to the Wickersham Commission concluded, among other things, that:

Witnesses were produced at the trials with information in the hands of the prosecution that seriously challenged the credibility of the witnesses but this information was deliberately concealed.

Witnesses were permitted to testify at the trials despite such knowledge in the possession of the prosecution of prior contradictory stories told by those witnesses, as to make their mere production a vouching for perjured testimony.

National Comm'n on Law Observance and Enforcement, Mooney-Billings Report 24243 (1931) (submitted to, but not released by, the Commission).

5294 U.S. at 112-13. The Court, citing earlier due process cases dealing with irregularities in the conduct of trials, focused on the notion that the alleged conduct of the prosecutor would render the judicial proceedings a "pretense of a trial" that would fail to meet due process standards. Hebert v. Louisiana, 272 U.S. 312 (1926); Frank v. Mangum, 237 U.S. 309 (1915); see Holmes's dissent in Frark: "Whatever disagreement there may be as to the scope of the phrase 'due process of law' there can be no doubt that it embraces the fundamental conception of a fair trial, with opportunity to be heard." Id. at 347 .

6317 U.S. 213, 216 (1942).

7 Pyle involved allegations both of perjury and suppression, which can of course be two sides of the same coin: the knowing use of false evidence can be considered a suppression of its falsity ( $a$ fact favorable to the defense), and favorable evidence may be suppressed in order to conceal the falsity of perjured testimony. 
the prosecutor but not suborned by him, and where the evidence was relevant only to sentencing ${ }^{8}$ or to the credibility of a prosecution witness ${ }^{9}$ rather than directly to the defendant's guilt.

In all of these cases, the Court focused on the conduct of the prosecutor; the central inquiry was whether the defendant had been denied a fair trial because of the improper role played by the prosecutor in obtaining his conviction. The Third Circuit's decision in U.S. ex rel. Thompson v. Dye $e^{10}$ marked a departure from the Pyle line of cases both in rationale and in application. Finding a denial of due process in the suppression of testimony that could have corroborated the defendant's exonerating claim of intoxication, the court ignored any issue of the prosecutor's blameworthiness and, instead, dealt only with the effect of the suppression on the defendant's ability to present his defense. The court held that whether the prosecutor's conduct had been willful or merely negligent, his failure to communicate favorable evidence had deprived the defendant of a fair trial. In a subsequent case, the Second Circuit applied the Thompson approach to the negligent suppression of evidence in the hands of government officials other than the prosecutor. ${ }^{11}$ In both Thompson and in the Second Circuit's decision, the focus was thus not whether the prosecutor had behaved improperly, but, rather, whether the defendant lacked access to information possessed by the government that could have changed the outcome of his trial.

In Brady v. Maryland, ${ }^{12}$ the Supreme Court finally spoke directly to the issue of prosecutorial suppression of evidence favorable to the accused and ratified the development of the fair trial concept that had

8 Alcorta v. Texas, 355 U.S. 28 (1957); see United States ex rel. Almeida v. Baldi, 195 F.2d 815 (3d Cir. 1952), cert. denied, 345 U.S. 904 (1953).

9 Napue v. Illinois, 360 U.S. 264 (1959).

10 United States ex rel. Thompson v. Dye, 221 F.2d 763 (3d Cir. 1955).

11 United States v. Consolidated Laundries Corp., 291 F.2d 563 (2d Cir. 1961); cf. Kyle v. United States, 297 F.2d 507 (2d Cir. 1961), cert. denied, 377 U.S. 909 (1964). But see Johnson v. Bennett, 386 F.2d 677 (8th Cir. 1967): "An interesting question is raised as to whether 'the prosecutor' is chargeable with the suppression of evidence for which the sheriff of another county of the state, apparently having no connection with the prosecutor, is responsible." Id. at 681 .

12373 U.S. 83 (1963). Brady was involved with one Boblitt in a robbery-murder and was convicted and sentenced to death. The prosecutor turned over to the defense all but one of Boblitt's statements to the police that the defense had requested. In the withheld statement, a retraction of an earlier one, Boblitt admitted that he had strangled the victim. The Maryland Court of Appeals ordered a new trial on the question of punishment only because under the felony murder rule Brady was guilty of murder no matter who did the killing. The Supreme Court held that Brady had not been denied a federal right in the restriction of the subject matter of the new trial. For a thorough exposition of the history and facts of the case and the life of John Leo Brady, see R. HAMMER, BETWEEN LIFE AND DEATH (1969). 
taken place in the lower courts: "We now hold that the suppression by the prosecution of evidence favorable to an accused upon request violates due process where the evidence is material either to guilt or to punishment, irrespective of the good faith or bad faith of the prosecution." 13 The Court said that the unfairness, and hence the violation of due process, inherent in the suppression of material exculpatory evidence stemmed from the prosecutor's role in helping to "shape a trial that bears heavily on the defendant."14 The Court thus stressed both the affirmative duty of the prosecution to ensure that criminal trials are fair and the harm caused defendants when prosecutors fail to meet this obligation.

\section{The Application of the Rule: Post-Brady Developments}

The Supreme Court's decision in Brady left unanswered important questions about the extent of the rule it announced and the procedure by which it was to be applied. Lower courts, and the Supreme Court itself, have encountered these problems in a variety of cases since Brady; their responses have often been inconsistent, not only with each other, but also with the due process concept of a fair trial upon which the Brady rule is premised.

\section{A. Necessity of a Request}

In Brady the defense had requested the suppressed evidence; the Supreme Court's holding, read literally, applies only to evidence that the defendant has asked the prosecutor to disclose. ${ }^{15}$ Nonetheless, several courts have held that a defense request is not a prerequisite to the operation of the Brady rule. ${ }^{16}$ Recently, however, in Moore $v$. Illinois, ${ }^{17}$ the Supreme Court reiterated the importance of the request

13373 U.S. at 87.

14 Id. at 88.

15 Justice Schaeffer of the Illinois Supreme Court, in his dissent in People v. Moore, 42 III. 2d 73, 89, 246 N.E.2d 299, 309 (1969), aff'd in part, rev'd in part, 408 U.S. 786 (1972), expressed his opinion that the Court in Brady had simply "used language appropriate to the decision of the case before it," and had not intended to impose a request requirement.

16 E.g., Barbee v. Warden, Md. Penitentiary, 331 F.2d 842 (4th Cir. 1964); United States ex rel. Meers v. Wilkins, 326 F.2d 135 (2d Gir. 1964); see Levin v. Clark, 408 F.2d 1209 (D.C. Cir. 1967) (reversal in absence of a request); Comment, Prosecutorial Misconduct: A National Survey, 21 DePaul L. REv. 422, 435-42 (1971). Indeed, the Supreme Court has itself reversed a conviction in the absence of a request. Giles v. Maryland, 386 U.S. 66 (1967). Justice Brennan noted in his plurality opinion that the trial court had "ordered a new trial, despite the absence of a pretrial request of defense counsel for disclosure of the evidence suppressed." Id. at 73. Justice Fortas, concurring, would have expressly removed the request requirement: "I see no reason to make the result turn on the adventitious circumstance of a request." Id. at 102.

17 Moore v. Illinois, 408 U.S. 786 (1972). 
element in its holding in Brady, ${ }^{18}$ although it did not decide whether a request is indispensable in all cases.

The basic argument for requiring a request stems from the central due process criterion of fairness and, in particular, from Brady's attention to the conduct of the prosecutor. It is simply more unfair for the prosecutor to fail to produce evidence that has been specifically requested than to fail to produce evidence of his own accord. Thus, although they have not ruled that a request is indispensable, two circuits have held that, in the absence of a request, the defense must make a stronger showing of materiality ${ }^{19}$ than it would had the request been made. ${ }^{20}$ As the Second Circuit explained, a defense request for specific information can serve "the valuable office of flagging the importance of the evidence for the defense and thus imposes on the prosecutor a duty to make a careful check of his files." 21 In close cases, therefore, the fact that the prosecutor has failed to disclose requested evidence that the defense believes to be material may lead the court to conclude that the trial was unfair even though the requested information would in fact have been of only marginal utility to the accused.

The "flagging" function described by the Second Circuit would not, of course, be served by a general request for all material favorable evidence. Such a request would merely remind the prosecutor of his constitutional duty, ${ }^{22}$ and would be little more than a sterile formalism. At the same time, however, if the defendant is unaware of the existence of evidence, he may be unable to make a specific request for its production. ${ }^{23}$ The defendant may not know, for example, that the state had conducted tests on physical evidence or that an eyewitness not called to testify at trial had stated that the defendant was not present

18 The Court said that "[t]he heart of the holding in Brady is the prosecution's suppression of evidence, in the face of a defense production request . . . . Important, then, are (a) suppression by the prosecution after a request by the defense . ...” Id. at 794. The dissenters argued that in fact there had been a request and therefore did not reach the issue of its necessity.

10 For a discussion of the materiality requirement, see text at notes 66-92 infra.

20 See Clarke v. Burke, 440 F.2d 853 (7th Cir. 1971), cert. denied, 404 U.S. 1039 (1972); United States v. Poole, 379 F.2d 645 (7th Cir. 1967); United States v. Keogh, 391 F.2d 138 (2d Cir. 1968); Kyle v. United States, 297 F.2d 507 (2d Cir. 1961); cf. Levin v. Clark, 408 F.2d 1209, 1216 (D.C. Cir. 1967) (Burger, J., dissenting).

21 United States v. Keogh, 391 F.2d 138, 147 (2d Cir. 1968).

22 Sometimes, apparently, this may be necessary. See Panel Discussion-Discovery in Criminal Cases, 44 F.R.D. 481, 501 (1967) (remarks of Jon Newman, former United States Attorney for Connecticut), discussed note 111 infra.

23 Giles v. Maryland, 386 U.S. 66, 102 (1967) (Fortas, J., concurring). This argument has also been made in Barbee v. Warden, Md. Penitentiary, 331 F.2d 842 (4th Gir. 1964); and People v. Moore, 42 Il. 2 d 73, 89-90, 246 N.E.2d 299, 306 (1969) (Schaeffer, J., dissenting); cf. Ashley v. Texas, 319 F.2d 80 (5th Cir.), cert. denied, 375 U.S. 931 (1963). 
at the scene of the crime. To hold a request indispensable would allow the prosecutor to suppress even evidence crucial to the defense so long as the defense was unaware of it. And since a defendant's knowledge of the existence of allegedly suppressed evidence is not readily susceptible to proof, it would be futile to require a request only when the defendant knows that the evidence exists.

It seems, therefore, unreasonable to make the request an indispensable element in the application of the Brady rule; the harm to the defendant, and hence the unfairness of the trial, may remain whether a request has been made or not. In practice, despite the Supreme Court's reiteration of the requirement in Moore, the great majority of courts seem to have taken this view, ${ }^{24}$ and judicial repetition of the request requirement may, in fact, only be intended to emphasize the desirability of a request whenever feasible.

\section{B. Timing of Disclosure}

The decision in Brady did not define the point in the proceedings against the defendant at which the prosecutor must disclose favorable evidence. Lower courts have generally divided between two alternatives: pretrial disclosure and disclosure at trial..$^{25}$ Disclosure at the time of sentencing ${ }^{26}$ or after the charge to the jury ${ }^{27}$ of material that could have been of use at trial has been held too late.

In responding to this question, the critical inquiry must be what is required in order to ensure a fair trial. As one court has noted, if evidence is to be of any use to the defendant at all, it must "be made available to him far enough in advance of trial to allow him sufficient

24 See authorities cited note 16 supra. Contra, United States ex rel. Felton v. Rundle, 410 F.2d 1300 (3d Cir. 1969) (en banc). In Felton, the trial judge told defense counsel he could recall the witness if necessary but denied him the opportunity to examine a relevant police report. The majority stressed that the attorney replied, "Very good, sir" to this denial; that is, he failed to object. Judge Biggs's dissent points out that the report would have been valuable to the defendant in itself, as well as to "open up other lines of inquiry to Felton's counsel." Id. at 1306. Thus the recall opportunity was an inadequate substitute.

25 Favoring pretrial disclosure: United States v. Bonnano, 430 F.2d 1060 (2d Cir.), cert. denied, 400 U.S. 964 (1970). United States v. Trainor, 423 F.2d 263 (1st Cir. 1970); United States v. Polisi, 416 F.2d 573 (2d Cir. 1969); United States v. Partin, 320 F. Supp. 275 (E.D. La.), appeal dismissed, 423 F.2d 556 (1970); United States v. Cullen, 305 F. Supp. 695 (E.D. Wis. 1969), aff'd, 454 F.2d 386 (1971); of. Famric v. Bailey, 386 F.2d 390 (4th Cir. 1967). Holding Brady limited to cases of suppression at trial: United States v. Moore, 489 F.2d 1107 (6th Cir. 1971); United States v. Condor, 423 F.2d 904, 911 (6th Cir.), cert. denied, 400 U.S. 958 (1970). ABA Standards Reiating to Discovery and Procedure Before Trial $\S \S 2.1(\mathrm{c}), 2.2(\mathrm{a})$ call for disclosure "as soon as practicable following the filing of charges against the accused." ABA Standards Relating to the Prosecution Function aNd the DEFEnSE Funcrion § 3.11 specifies disclosure "at the earliest possible opportunity."

26 United States ex rel. Butler v. Maroney, 319 F.2d 622 (3d Cir. 1963).

27 Hamric v. Bailey, 386 F.2d 390 (4th Cir. 1967). 
time for its evaluation, preparation and presentation . . . ."28 Certain kinds of evidence-for example, some impeachment evidence-may be of use to the defendant only at trial. But most evidence is valuable for pretrial preparation. The questioning of favorable witnesses may lead to the discovery of material evidence. Weaknesses in the prosecution's case can be exploited through research. Any favorable evidence may be strengthened by corroboration discovered by means of additional investigative work. In short, the whole theory and presentation of the defense may be revised. Because of the multiple uses to which defendants can put disclosed information in preparing their defense, pretrial disclosure seems the desirable alternative. ${ }^{29}$

Although few courts have ruled directly against pretrial disclosure, ${ }^{30}$ appeals based on belated disclosure have generally failed. Some courts have avoided the timing problem either by holding that the defendant had not been prejudiced by the delay ${ }^{31}$ or that he had failed to sustain the burden of proving prejudice. ${ }^{32}$ If, however, a defendant has been denied evidence until trial, it may be difficult for him to use the evidence to conduct the investigations and research necessary to establish that the denial was prejudicial. In recognition of this, and to clarify the duty of the prosecutor, courts should find error in any delay in disclosure, holding the error harmless and affirming the conviction only when it is convinced that delay had no prejudicial effect. ${ }^{33}$

A particularly difficult timing problem arises when evidence subject to disclosure under Brady is also subject to the Jencks Act provision

28 United States v. Partin, 320 F. Supp. 275, 285 (E.D. La. 1970). See also Hamric v. Bailey, 486 F.2d 390 (4th Gir. 1967). United States v. Cullen, 305 F. Supp. 695 (E.D. Wis. 1969); United States v. Ball, 49 F.R.D. 153 (E.D. Wis. 1969).

20 Where there is specific reason to fear witness intimidation or attempted fabrication, or the court determines that the policy behind the Jencks Act's prohibition warrants a delay, some compromise in the form of the Jencks Act provision in section 3500 (c), incorporating the right to a reasonable continuance, could be required. For the text of section 3500 (c), see note 38 infra.

30 See cases cited note 25 supra.

31 United States v. Jordan, 399 F.2d 610 (2d Cir. 1968).

32 United States v. Elmore, 423 F.2d 775 (4th Cir.), cert. denied, 400 U.S. 825 (1970). (Prosecutor had met pretrial motion for Brady disclosure with a denial that he had such evidence, but then disclosed some at trial. Denial of defendant's motion for a mistrial was affrmed due to failure to request a continuance and court's conclusion that he had sufficient time to make use of the evidence at trial.); United States v. Trainor, 423 F.2d 263 (Ist Cir. 1970) (Defendant's claim that all Brady material must be disclosed before trial was rejected. The court said it would require pretrial disclosure where necessary in fairness to the defendant but held that since the information, a witness's prior statement, was useful to the defense only for the purpose of impeachment and could have been of no help in pretrial preparation, the delay in disclosure required by the Jencks Act was not prejudicial.)

33 For a discussion of harmless error in Brady rule cases, see text at notes 92-95 infra. 
requiring that past statements of government witnesses not be disclosed until they have testified at trial. ${ }^{34}$ If Jencks Act statements contain material evidence favorable to the accused, and if the Brady rule is read to require pretrial disclosure, the statute and the rule conflict. Some courts have held that statements of government witnesses need never be disclosed until the Jencks Act permits. ${ }^{35}$ Others, although approving the Jencks Act requirement in general, have held that evidence so "obviously exculpatory and of such a nature that delay in disclosure would prevent the defendant from effectively using it at trial" must be turned over before trial; if it is not, the court may grant a motion for a mistrial. ${ }^{36}$ Only one appellate decision has dealt with this conflict between the Jencks Act and the Brady rule. In United States $v$. Trainor, ${ }^{37}$ the First Circuit denied relief to the defendant, but at the same time it clearly implied that if the statement in question contained material useful to the defendant at the pretrial stage, the prosecutor's failure to disclose at that time would have required reversal.

Defense counsel are perhaps most likely to encounter problems when the prior statement of a prosecution witness contains evidence useful to the defense at the pretrial stage but unrelated to the witness's trial testimony. The provisions of the Jencks Act deny such statements to the defense altogether. If the in camera inspection that the Act calls for ${ }^{38}$ fails to alert the judge to the significance of the statements, defense

3418 U.S.C. $\$ 3500$ (1970): “(a) In any criminal prosecution brought by the United States, no statement or report in the possession of the United States which was made by a Government witness or prospective Government witness (other than the defendant) shall be the subject of subpoena, discovery, or inspection until said witness has testified on direct examination in the trial of the case. (b) After a witness called by the United States has testified on direct examination, the court shall, on motion of the defendant, order the United States to produce any statement (as hereinafter defined) of the witness in the possession of the United States which relates to the subject matter as to which the witness has testified. ..."

35 United States v. Wolfson, 289 F. Supp. 903 (S.D.N.Y. 1968), rev'd on other grounds, 437 F.2d 862 (1970); United States v. Manhattan Brush Co., 38 F.R.D 4. (S.D.N.Y. 1965).

36 United States v. Cobb, 271 F. Supp. 159, 164 (S.D.N.Y. 1967).

37423 F.2d 263 (1st Cir. 1970).

3818 U.S.C. $\$ 3500$ (c) (1970): "If the United States claims that any statement ordered to be produced under this section contains matter which does not relate to the subject matter of the testimony of the witness, the court shall order the United States to deliver such statement for the inspection of the court in camera. Upon such delivery the court shall excise the portions of such statement which do not relate to the subject matter of the testimony of the witness. With such material excised, the court shall then direct delivery of such statement to the defendant for his use. . . . Whenever any statement is delivered to a defendant pursuant to this section, the court, in its discretion, upon application of said defendant, may recess proceedings in the trial for such time as it may determine to be reasonably required for the examination of such statement by said defendant and his preparation for its use in the trial." 
counsel may have to argue on appeal, citing Trainor, that insofar as it denies the defendant access to information that must be disclosed under the Brady rule, the Jencks Act is unconstitutional. ${ }^{39}$

\section{Who Decides What Is Favorable}

Brady did not specify whether the defense, the trial judge, or the prosecutor was to determine what information in the prosecutor's file is favorable to a defendant and of sufficient materiality that disclosure is required. If the defense were allowed to make this determination, complete disclosure of the prosecutor's files would of course be necessary. No court has required this procedure, and many have expressly rejected arguments that $B r a d y$ requires it..40

Most courts have also rejected the alternative of in camera inspection by the court, ${ }^{41}$ usually on the ground that it is impractical in terms of judicial economy. It has also been pointed out that general in camera inspection could raise the possibility of judicial bias in cases in which the same judge inspected the file and tried the case. ${ }^{42}$ In addition to these objections, allowing the court to make this determination might well prove unsatisfactory to the defense since, pretrial and in the trial's early stage, a judge is probably less likely than a prosecutor to be able to identify what evidence can be considered favorable to the defendant's case.

While judicial inspection of the entire file is unusual, courts have agreed to inspect specific material to determine whether it must be disclosed. In several cases in which the defense had requested grand jury testimony and had either been told that there was nothing exculpatory ${ }^{43}$ or been given excerpts and told that nothing else was favorable, ${ }^{44}$ trial

39 See United States v. Augenblick, 393 U.S. 348, 356 (1969), on Brady-Jencks problems. There may also be some implicit conflict between Brady and the Court's decision in Roviaro v. United States, 353 U.S. 53 (1957); see United States v. Russ, 362 F.2d 843 (2d Cir.), cert. denied, 385 U.S. 923 (1966).

40 United States v. Evanchik, 413 F.2d 950 (2d Cir. 1969); United States v. Harris, 409 F.2d 77 (4th Cir. 1969); United States v. Avella, 395 F.2d 762 (3d Cir. 1968). For a discussion of this possibility, see text and notes at notes 108-35 infra.

41 United States v. Frazier, 394 F.2d 258 (4th Cir. 1968); United States v. Cobb, 271 F. Supp. 159 (S.D.N.Y. 1967). But see Scalf v. Bennett, 408 F.2d 325 (8th Cir. 1969) (where, after defendant alleged suppression had occurred, trial judge, and on appeal the circuit court, searched record and found none); Hensley v. United States, 406 F.2d 481, 485 (10th Cir. 1968) (holding that, while it was error for trial judge to delay examination of prosecutor's files until after trial, fact that he found no Brady material indicated defendant was not prejudiced.)

42 See Panel Discussion-Discovery in Criminal Cases, supra note 22, at 499 (remarks of Jon Newman, former United States Attorney for Connecticut).

43 Pollard v. United States, 441 F.2d 566 (7th Cir. 1971).

44 Xydas v. United States, 445 F.2d 660 (D.C. Cir.), cert. denied, 404 U.S. 826 (197I). 
judges have inspected the testimony to determine whether the prosecutor had fulfilled his disclosure duty. ${ }^{45}$ In Xydas $v$. United States, ${ }^{46}$ the inefficacy of this procedure was demonstrated by the postconviction discovery that the testimony examined by the trial court did indeed contain statements favorable to the accused.

The courts' rejection of both defense and court inspection of the prosecutor's file leaves one alternative: it is the duty of the prosecutor to police himself, to remain alert for aspects and implications of evidence that might be favorable to the accused, and to make disclosure on his own initiative. The prosecutor is, perhaps, best able to assemble and transmit the evidence in the government's possession. But because this duty forces the prosecutor into a role that is, to some extent at least, in conflict with his major task of pursuing convictions, it is necessary for the courts to assess his performance in light of the underlying goal in Brady-ensuring a fair trial for all defendants-and to impose sanctions when his performance is inadequate. ${ }^{47}$ Although the courts have assigned to the prosecutor the burden of determining what material must be disclosed to ensure a fair trial, he must exercise this function from a defense perspective, ${ }^{48}$ and it may be unrealistic to suppose that an adversary can act with the objectivity this requires.

\section{What Constitutes Suppression}

The conduct that Brady termed "suppression" can better be called nondisclosure. The latter term lacks the connotation of intention in the former and, therefore, more accurately reflects the case law development. The movement of cases from Mooney to Brady has been analyzed as a change from a focus on the willful misbehavior of the prosecutor to a focus on the harm to the defendant. ${ }^{40}$ Comparison of the suppression cases to the similar but distinct line of cases concerning newly discovered evidence demonstrates, however, the importance of the prosecutor's conduct in the constitutional fair trial concept.

Newly discovered evidence is not favored as a basis for a new trial; ${ }^{50}$

45 But see United States v. Eustace, 423 F.2d 569 (2d Cir. 1970), in which the trial court's refusal to undertake even such a limited inspection was affirmed.

46445 F.2d 660 (D.C. Cir.), cert. denied, 404 U.S. 826 (1971). The defendant's conviction was affirmed on the ground that the favorable statements were immaterial.

47 For a discussion of the prosecutor's role, see text at notes 93-107 infra.

48 See Barbee v. Warden, Md. Penitentiary, 331 F.2d 842, 845 (4th Cir. 1964); Griffin v. United States, 183 F.2d 990, 993 (D.C. Cir. 1950): "Where there is substantial room for doubt, the prosecution is not to decide for the court what is admissable or for the defense what is useful."

49 Note, The Prosecutor's Constitutional Duty to Reveal Evidence to the Defendant, 74 YALE L.J. 136 (1964); see text at notes 3-14 supra.

50 United States v. De Marie, 261 F.2d 477 (7th Cir. 1959). 
to secure a new trial, the defendant must generally show that, because of the newly discovered evidence, the trial would probably result in his acquittal. ${ }^{51}$ The standard of materiality applied under the Brady rule is clearly not this high: something less than the probability of a different result suffices. ${ }^{52}$ The only difference between the newly discovered evidence cases and the Brady cases that can account for this difference in treatment is that, in the latter, the government knew of the existence of the evidence. Thus, a defendant cannot obtain a new trial if there is only a possibility that newly discovered evidence would lead to his acquittal; nor can he obtain a new trial if he has failed to exercise due diligence in uncovering evidence that probably would have led to his acquittal. ${ }^{53}$ In the Brady cases, however, the courts see greater unfairness, and therefore require a much lesser showing of harm, apparently because the unavailability of the evidence resulted from the action or inaction of the state. ${ }^{54}$

In addition to this perceived difference in the degree of unfairness to the defendant, newly discovered evidence cases and nondisclosure cases present very different problems for the administration of justice. Criminal defendants will always have an incentive to attempt to dis-

51 United States v. Martinez, 496 F.2d 12 (9th Gir. 1970), cert. denied, 401 U.S. 959 (1971); United States v. Craft, 421 F.2d 693 (9th Cir. 1970). The general rule is stated in Berry v. Georgia, $10 \mathrm{Ga} .511,527$ (1851):

Upon the following points there seems to be a pretty general concurrence of authority, viz: that it is incumbent on a party who asks for a new trial, on the ground of newly discovered evidence, to satisfy the Court, 1st. That the evidence has come to his knowledge since the trial. 2d. That it was not owing to the want of due diligence that it did not come sooner. 3d. That it is so material that it would probably produce a different verdict, if the new trial were granted. 4 th. That it is not cumulative only -viz; speaking to facts, in relation to which there was evidence on the trial. 5th. That the affidavit of the witness himself should be produced, or its absence accounted for. And 6 th, a new trial will not be granted, if the only object of the testimony is to impeach the character or credit of a witness.

While the Berry rule is usually followed, an alternate and more liberal formulation, said to be applicable only in cases of recantation by a witness, United States v. Johnson, 327 U.S. 106, 111 n.5 (1946), was enunciated in Larrison v. United States, 24 F.2d 82, 87 (7th Cir. 1928), which held that a new trial should be granted because of newly discovered evidence when "without it the jury might have reached a different conclusion."

52 See text at notes 66-92 infra.

53 Cf. United States v. Passero, 290 F.2d 238, 245 (2d Cir.), cert. denied, 368 U.S. 819 (1961). While this is theoretically true under the Berry rule, courts can either find due diligence or avoid the rule if the likelihood of acquittal on retrial is great.

54 Newly discovered evidence and suppression cases differ in other respects as well. Impeachment evidence, which will not generally suffice in the former, may warrant reversal in the latter. Compare United States v. Craft, 421 F.2d 693 (9th Cir. 1970) and Gordon v. United States, 383 F.2d 936 (D.C. Cir. 1967), cert. denied, 390 U.S. 1029 (1968) with Napue v. Illinois, 360 U.S. 264 (1959) and Ingram v. Peyton, 367 F.2d 933 (4th Cir. 1966). The "merely cumulative" doctrine, which is a substantial bar to reversal in the former, United States v. Dara, 429 F.2d 513 (5th Cir. 1970), has been less significant in the Iatter. See text and notes at notes $82-84$ infra. 
cover an additional shred of evidence that might arguably have made a difference at trial. So long as defendants have been accorded fair trials, with the opportunity to discover and present evidence, the problem for courts is to preserve the finality of judgments and prevent constant retrials in all but exceptional cases. Suppression of evidence can be avoided, however, only if the courts define clear standards for disclosure and impose sanctions whenever these standards are breached.

Although suppression need not be intentional, courts have generally expected some showing that the prosecutor has been negligent, that there was reason for him to believe that the evidence might be useful to the defense. This requirement is correlated, at least in part, to the materiality standard. If the prosecutor was aware of certain evidence but unaware that it was favorable to the accused, the materiality of the evidence-and the negligence of the prosecutor-may seem doubtful; ${ }^{55}$ by the same token, if the evidence is obviously important, prosecutorial negligence can be assumed. A defendant may be harmed by the nondisclosure of any favorable evidence, but whether this harm is of constitutional significance and renders the trial unfair may depend on the standard of negligence that the courts set for prosecutors: if the standard of negligence is high, the required showing of materiality may be correspondingly low.

Some recent cases indicate that the standard of care imposed on prosecutors may be quite high. The Supreme Court has held that although the loss of Jencks Act statements does not automatically equal suppression, the government must show that it has made a good faith effort to preserve them. ${ }^{56}$ The District of Columbia Circuit has ruled that "before a request for discovery has been made the duty of disclosure is operative as a duty of preservation." 57 In some circumstances,

55 The evidence could, of course, be very useful: The defense might have information which, together with something in the prosecutor's file, could prove crucial, but without this defense information, the prosecutor could well be unaware of the importance of his own information to the defense. This possibility supports the argument for complete disclosure. See text at notes 108-35 infra.

58 United States v. Augenblick, 393 U.S. 348 (1969).

57 United States v. Bryant, 439 F.2d 642, 651 (D.C. Cir. 1971). On remand, 331 F. Supp. 927 (1971), and reappeal, 448 F.2d 1182 (1971), it was determined that the agent had indeed been negligent in the loss of a recorded conversation that the defendant had a right to have disclosed under Brady, the Jencks Act and FED. R. CrIM. P. 16. The court said that, although reversal would normally be required, the tape was apparently garbled and inaudible and of no practical use to the defendant. This, combined with the strong evidence against the defendant, outweighed the error of the loss and warranted affirming. On the specific problem of destruction of evidence, a form of suppression with its own special problems since favorability and materiality can no longer be determined, see Comment, Judicial Response to Governmental Loss or Destruction of Evidence, 39 U. CHI. L. REv. 542 (1972). 
the prosecutor may be required to take affirmative action to secure evidence favorable to the accused. One court has suggested, for example, that the failure of the prosecutor and investigating officers to conduct investigations that could reveal exculpatory information might constitute suppression. ${ }^{58} \mathrm{~A}$ similar issue arises when the prosecution refuses to offer immunity to a prospective witness whose testimony would clearly be relevant and probably favorable to the defendant. ${ }^{50}$ Although the government may in many cases have good reason to avoid granting immunity, if his testimony is likely to be crucial to the defense and if the witness is not under indictment in connection with the matters that his testimony would concern, the prosecution's refusal to obtain the testimony seems tantamount to suppressing it. ${ }^{60}$

To constitute suppression, the government must at one time have possessed the evidence or at least had access to it; ${ }^{61}$ the prosecutor,

58 See Peoples v. Hocker, 423 F.2d 960 (9th Cir. 1970), in which defendant's murder conviction was upheld in an appeal alleging suppression by the police in failing to take paraffin tests for gunpowder to determine if the deceased had committed suicide. The court's rationale was not that the police have no duty to seek evidence for the defense, but that, although the tests might better have been performed, the investigation was not so poor as to constitute a denial of due process. In this case, as in many suppression cases, the overwhelming weight of the evidence against the defendant may also have contributed to the result.

59 See Earl v. United States, 361 F.2d 531 (D.C. Cir. 1966), cert. denied, 388 U.S. 921 (1967), which held that refusal to grant immunity did not constitute suppression (at least where the offer would probably not have induced the testimony anyway). The court split four to four on a motion for rehearing en banc. It is clear that suppression constitutes keeping evidence from the defendant for use in connection with his trial. Failure to present evidence favorable to the defendant to the grand jury is not grounds to quash the indictment for suppression even though, had the evidence been offered, the indictment might not have been returned. Loraine v. United States, 396 F.2d 335 (9th Cir. 1968).

60 Cf. 18 U.S.C. § 6003, providing that the United States Attorney may request the court to confer immunity to obtain testimony in certain cases when, in his judgment, the testimony of the witness "may be necessary to the public interest." When the government declines to do so, an alternative remedy to appellate reversal for suppression would appear to be a missing witness instruction by the trial judge. Such an instruction would inform the jury that the government's failure to obtain the testimony raises a presumption that it would be favorable to the defense. See Graves v. United States, 150 U.S. 118, 121 (1893); McAbee v. United States, 294 F.2d 703 (D.C. Cir. 1961), cert. denied, 382 U.S. 854 (1965); Richards v. United States, 275 F.2d 655 (D.C. Cir.), cert. denied, 363 U.S. 815 (1960). Such an instruction would, however, encourage the prosecutor to gamble that the jury would presume little, particularly where the witness's testimony was strongly favorable and material. In such a case it would be especially important that the testimony be obtained and the stronger sanction of reversal might be necessary to prod the prosecutor to do so through an offer of immunity.

61 See Peoples v. Hocker, 423 F.2d 960 (9th Cir. 1970). A prosecutor's warning to an important witness not to talk to defense counsel has been held to be suppression of the means of obtaining evidence and close enough to actual suppression of evidence to support the reversal of a conviction. Gregory v. United States, 369 F.2d 185 (D.C. Cir. 1966); cf. Traynor, Ground Lost and Found in Criminal Discovery, 39 N.Y.U.L. REv. 228 (1964): “A 
however, need not have possessed the evidence so long as it was in the custody of other government agents. The suppression of favorable documents by government agents, ${ }^{62}$ a favorable ballistics report known to the police, ${ }^{63}$ and a policeman's knowledge that a witness is giving false testimony ${ }^{64}$ have all been held chargeable to the prosecution. Thus, under the Brady rule, the government is treated as an entity and the knowledge of any government agent may be imputed to the prosecutor. ${ }^{65}$

\section{E. "[W]here the evidence is material either to guilt or to punishment . . . ."}

The most difficult problem created by the Brady decision has been that of materiality. Although the Court's use of the term "material" could at the time have been taken to mean only that the evidence must be relevant, lower courts, and the Supreme Court itself in subsequent cases, have read into the word a standard for the degree of harm that the suppression must have caused the defendant to require the reversal of his conviction. Perhaps because of the myriad fact situations in which suppression claims can arise, courts have found it impossible to define a materiality standard of general applicability.

Materiality, as it is used in the Brady cases, has two components. The first is the extent to which the evidence is favorable to the accused. If, for example, one of only two eyewitnesses to a crime had told the prosecutor that the defendant was definitely not its perpetrator and if this statement was not disclosed to the defense, no court would hesitate to reverse a conviction resting on the testimony of the other eyewitness. But if there were fifty eyewitnesses, forty-nine of whom identified the defendant, and the prosecutor neglected to reveal that the other, who was without his badly needed glasses on the misty evening of the crime, had said that the criminal looked something like the defendant but he could not be sure as he had only had a brief glimpse, the result might well be different. The second component of the materiality standard is the relevance of the evidence to the issue of

defendant has hardly had a fair trial if he has been denied the opportunity to discover evidence or information crucial to his defense."

62 Kyle v. United States, 297 F.2d 507 (2d Cir. 1961).

63 Barbee v. Warden, Md. Penitentiary, 331 F.2d 842 (4th Cir. 1964).

64 Imbler v. Craven, 298 F. Supp. 795 (C.D. Cal. 1969), aff'd, 424 F.2d 630, cert. denied, 400 U.S. 865 (1970). This may be true even when the policeman is not present in the courtroom when the testimony is given. See Luna v. Beto, 391 F.2d 329 (5th Cir. 1967).

65 See text and note at note 71 supra. But see Johnson v. Bennett, 386 F.2d 677 (8th Cir. 1967), discussed note 11 supra. 
the defendant's guilt or innocence. ${ }^{68}$ Eyewitnesses' reports would clearly be relevant; ${ }^{67}$ evidence that the defendant would not have used at trial but that would have secured him a procedural advantage might not be relevant. ${ }^{68}$ Both of these factors-favorability and relevanceare, however, so difficult to measure that the courts, instead of dealing with each separately, attempt to answer, in light of all the evidence, the conclusive question: Would disclosure of the evidence in question have changed the outcome of the trial? The difficulty involved in making this decision, which is in any case necessarily based on hindsight, is exacerbated by the fact that the trial may have been distorted by the defendant's inability to use the suppressed evidence to prepare.

The three suppression cases that the Supreme Court has taken since Brady have not clarified the materiality standard. In Giles v. Maryland ${ }^{69}$ the Court reversed a rape conviction on the ground that the prosecutor had failed to disclose that the prosecutrix had retracted another rape charge. Perhaps because of the importance of this evidence, the majority was able to decide the case without reference to an explicit standard of materiality; ${ }^{70}$ whatever the standard, the evidence was material.

Giglio $v$. United States ${ }^{71}$ dealt with the materiality of a statement of the key prosecution witness; the assistant United States attorney who

66 The reversal, in one case, for the suppression of evidence relevant only to the impeachment of a prosecution witness represented an extension of the doctrine since it was not directly material to guilt. Ingram v. Peyton, 367 F.2d 933 (4th Cir. 1966); cf. Napue v. Illinois, 360 U.S. 264 (1959).

67 See Weaver v. United States, 418 F.2d 475 (8th Cir. 1969); Lee v. United States, 388 F.2d 737 (9th Cir. 1968).

68 See, e.g., United States v. Teague, 445 F.2d 114 (7th Gir. 1971) (defendant convicted of bank robbery on eyewitness testimony held not prejudiced by prosecutor's failure to disclose eyewitness to almost simultaneous robbery of nearby postal substation); Flores v. United States, 379 F.2d 905, 910 n.6 (5th Cir. 1967).

69386 U.S. 66 (1967).

70 The opinions did discuss whether suppression of inadmissable evidence could warrant reversal. Justice Brennan's plurality opinion, in which Chief Justice Warren and Justice Douglas joined, made contradictory statements on the subject, both implying that it could, ("the defense might have made effective use of the report at the trial or in obtaining further evidence." $I d$. at 74) and, by implication, that it could not ("whether the prosecution's constitutional duty to disclose extends to all evidence admissable . . . ." Id. at 74). Justice Fortas responded in his concurrence, "I do not agree that the State may be excused ... solely because of a conclusion that they would not be admissible at trial. . . . No respectable interest of the State is served by concealment of information which is material, generously conceived, to the case, including all possible defenses." Id. at 98. This issue has not been directly presented on appeal but it is hard to believe that the suppression of an important exculpatory statement would not warrant reversal merely because it was hearsay. For cases concerning the pretrial use of suppressed evidence, see cases cited note 25 supra.

71405 U.S. 150 (1972). Chief Justice Burger wrote the opinion for a unanimous court. 
presented the case to the grand jury knew that the statement was false, but the trial attorney, who left the statement uncorrected, did not. In describing the materiality standard, the Court said, quoting the Napue decision, that "[a] new trial is required if "the false testimony could ... in any reasonable likelihood have affected the judgment of the jury ...."72 The Court did not further clarify the test. But since the Court concluded that the suppressed evidence would have severely undermined the credibility of the witness on whose testimony the prosecution's case almost entirely depended, a precise articulation of the materiality standard was perhaps unnecessary to the decision. As in Giles, reversal would have been required under almost any standard.

In Moore $v$. Illinois, ${ }^{73}$ an extremely complex murder case, the Supreme Court again failed to articulate a standard for judging the materiality of undisclosed favorable evidence. Moore was convicted on the eyewitness testimony of two persons and the corroborated testimony of one Sanders that he had heard Moore boast of the crime. Moore's defense was alibi and mistaken identification; he presented one witness to an incident involving the murderer and the victim that had occurred just before the crime, who testified that Moore was not the criminal. ${ }^{74}$ The major items of evidence suppressed were Sanders' original statement to the police identifying the speaker as "Slick" and other evidence showing that "Slick" and Moore could not have been the same man. The Court affirmed the conviction, the majority concluding that "Sanders' misidentification of Moore as Slick was not material to the issue of guilt," and that "the background presence of the elusive 'Slick,' while somewhat confusing, is at most an insignificant factor."75 Only the dissent made any attempt to describe the standard by which materiality must be measured: "While frivolous information and useless leads can be ignored, if evidence is clearly relevant and helpful to the defense, it must be disclosed." 76 The dissenters concluded, quoting Justice Schaefer's dissent in the Illinois Supreme Court, that had the suppressed facts been available to it, " the jury may well have been

72 Id. at 154; see text and note at note 9 supra.

73408 U.S. 786 (1972), a five-to-four decision with Justice Marshall's dissent joined by Justices Douglas, Stewart, and Powell. Justice Brennan's vote, and particularly his silence, is surprising in light of his expressed views on this subject. See Brennan, J., supra note 1.

74 The link between this incident and the murder was never conclusively established. Although one prosecution witness identified Moore both times, all parties involved in the case assumed the two were the same person.

75408 U.S. at 797-98. It is too early to assess the effect of this holding, but a decision by the Supreme Court that the proven misidentification of defendant by a prosecution witness was not material to guilt in a case in which the crucial factual issue was identification, does not augur well for the extension of defendant's disclosure rights.

76 Id. at 809 . 
unwilling to act upon the identifications of [the other two main prosecution witnesses]." "77

In a murder trial with conflicting eyewitness testimony and a defense of alibi and mistaken identity, it seems, at the very least, questionable to hold immaterial evidence that an important prosecution witness had mistaken the defendant for someone else. The Court's majority focused on the question of Moore's guilt and concluded that the suppressed evidence did not destroy the prosecution's case. ${ }^{78}$ But this does not answer the necessary due process inquiry: Was Moore accorded a fair trial? The question should have been whether Moore's attorneys might have put the evidence to use in preparing or presenting their client's case. If so-and the conclusion seems inescapable that they could have-_"the State's nondisclosure denied the defendant the fundamental fairness guaranteed by the constitution." 79

Lower court opinions often read as if the judge has first made up his mind as to the defendant's guilt and then simply decided the materiality issue accordingly. In one case, for example, in which the government failed to inform the defense of evidence that other strange vehicles and men in addition to the defendant had been seen near a bank on the night of the robbery of which the defendant was accused, the court held that the evidence was immaterial, given the strong, though circumstantial, evidence of the defendant's guilt. ${ }^{80}$ In another case, in which the defendant on a rape charge was misinformed by the prosecution as to the results of a psychiatric examination of the victim, the district court found that "the jury would not have reached a different verdict had the report been disclosed." The Ninth Circuit affirmed, holding the nondisclosed evidence immaterial. ${ }^{81}$

77 Id. at 806.

78 "The attempt to identify Moore as 'Slick' encountered difficulty, but nothing served to destroy the two-witness identification of Moore as Zitek's assailant, the three-witness identification of Moore as present at the Ponderosa Tap, the two-witness identification of Moore as one of the men who requested and obtained a ride from the Ponderosa in Dolton to Harvey, Illinois and Fair's testimony as to the admission made on that ride." Id. at 798. This assertion is extremely questionable: the misidentification by Sanders cast grave doubt on the identifications made by the others at the Ponderosa, and in connection with the ride, since none of them knew "Slick" as well as Sanders did and they were thus more likely to make a mistake in identification.

79 People v. Moore, 42 Ill. 2d 73, 88-89, 246 N.E.2d 299, 308 (1969) (Schaeffer, J., dissenting), aff'd in part, rev'd in part, 408 U.S. 726 (1972).

80 Peterson v. United States, 411 F.2d 1074 (8th Gir. 1969).

81 Stout v. Cupp, 426 F.2d 881 (9th Gir. 1970). The defendant's confession, which survived attack in the same appeal, probably influenced the court's speculation as to the effect of the nondisclosed evidence on the jury. See Lessard v. Dickson, 394 F.2d 88 (9th Cir. 1968) (failure to tell defendant that motel operator saw stranger, not defendant, go into deceased's room shortly before body was found, held not material in light of the massive 
Gourts that have affirmed convictions have not generally indicated how much more convincing the nondisclosed evidence would have to have been to have warranted reversal. It is possible to construe an absolute finding that the jury would not have reached a different result as implying that if there is any doubt whatever about the effect that the nondisclosed evidence would have had on the jury, a new trial must be ordered. It is unlikely, however, that this is the implication the courts intended. Rather, such speculation about effect on the jury seems often to mean only that the court believes the defendant guilty and therefore assumes that a jury would agree.

It has frequently been stated that evidence that is merely cumulative does not justify reversal. ${ }^{82} \mathrm{~A}$ finding that evidence is cumulative is, clearly, simply another way of denying the usefulness of the evidence to the defendant. It may be, however, that an accumulation of evidence could have an effect on the jury even though a single item did not; ${ }^{83}$ it is impossible to know what quantum of evidence would have changed the jury's conclusion. In addition, evidence that seems merely cumulative may come from a source that the jury might find uniquely believable. ${ }^{84}$ The "merely cumulative" doctrine often amounts to little more than a speculative conclusion about the effect on all jurors of an entire category of evidence. This is, perhaps, preferable to the appellate court drawing its own conclusion as to the defendant's guilt, but it is

weight of evidence against defendant); U.S. v. Tomaiolo, 378 F.2d 26 (2d Cir. 1967) ("evidence wholly lacking in probative force because of its speculative quality"). But see Hamric v. Bailey, 386 F.2d 390 (4th Cir. 1967) (evidence is material if it would be mere speculation to say that it could not have influenced the factinder).

82 This doctrine was probably first brought to suppression cases from the Berry $v$. Georgia rule for newly discovered evidence, see note 51 supra, in Justice Fortas's otherwise expansive concurring opinion in Giles v. Maryland, 386 U.S. 66, 100 (1967): "If it has in its exclusive possession specific, concrete evidence which is not merely cumulative or embellishing ... the State is obligated to bring it to the attention of the court and the defense." See Rhinehart v. Rhay, 440 F.2d 718 (9th Cir.), cert. denied, 404 U.S. 825 (1971); Government of the Virgin Islands v. Lovell, 410 F.2d 307 (3d Cir. 1969); Luna v. Beto, 395 F.2d 35 (5th Cir. 1968) (en banc); cf. 8A J. Moore, Federal Practice $\$ 33.03$ (1), for the use of the "merely cumulative" doctrine in motions for a new trial based on newly discovered evidence. While this standard may be desirable when dealing with true newly discovered evidence cases, it seems inappropriate when the evidence is newly discovered by the defense but was known all along by the prosecution. For a comparison of the newly discovered evidence and suppression cases, see text and notes at notes 50-54 supra.

83 Government of the Virgin Islands v. Lovell, 410 F.2d 307, 312 (3d Cir. 1969) (dissenting opinion).

84 Rhinehart v. Rhay, 440 F.2d 718 (9th Cir. 1971). The district court's order of new trial was reversed on the ground that the evidence was merely cumulative. The disputed evidence was a policeman's recorded suspicion that the prosecution witness in this sodomy case was a male prostitute. The defense had already presented this theory through another witness but would no doubt have been eager to have the idea reach the jury through a policeman. 
nonetheless an objectionable departure from the proper constitutional question of the fairness of the trial. Whatever standard of materiality is imposed, it seems particularly improper to hold suppressed evidence immaterial simply because it can be termed "cumulative."

Judge Friendly has been the leading proponent of a multiple standard of materiality. ${ }^{85}$ In cases in which the suppression was a deliberate obstruction or failure to disclose obviously valuable information, the evidence is "almost by definition ... highly material." 86 In cases in which the defense has made a request-presumably for specific evidence rather than all favorable information-the prosecutor is forewarned that the defense considers the evidence important and has a duty to make a careful check of his files. ${ }^{87}$ In both kinds of cases, if suppression has occurred, Judge Friendly would reverse almost automatically. In a third kind of case, however, in which the suppression was not deliberate and no request had been made, but "hindsight discloses that the defense could have put the evidence to not insignificant use,"88 Judge Friendly would impose a much higher standard of materiality. ${ }^{89}$ This three-tiered approach to the materiality problem takes into account the two components of the fair trial concept in Brady: usefulness to the defense and the conduct of the prosecutor. If, however, the prosecutor is to have the task of selectively disclosing favorable evidence from his files, it is unfair to the accused not only

85 United States v. Keogh, 391 F.2d 138 (2d Gir. 1968); Kyle v. United States, 297 F.2d 507 (2d Cir. 1961), cert. denied, 377 U.S. 909 (1964); see Link v. United States, 352 F.2d 207 (8th Cir. 1965), cert. denied, 383 U.S. 915 (1966), holding that suppressed impeachment evidence requires a higher standard of materiality than would be imposed for evidence directly relevant to guilt. This may merely mean that because impeachment evidence is inherently less relevant, it must be correspondingly more favorable to require reversal. The court proposed a very liberal materiality standard for evidence directly relevant to guilt: "Evidence material to guilt is, we think, evidence which is of probative character on that question." Id. at 212. But see Alcorta v. Texas, 355 U.S. 28 (1957), on the irrelevance of distinguishing impeachment evidence.

86 United States v. Keogh, 391 F.2d 138, 147 (2d Cir. 1968). While this is obviously true for crucial information like Boblitt's confession in Brady or the existence of a favorable eyewitness, it is not as clear for all cases of deliberate obstruction. It is possible that the prosecutor could deliberately withhold information of questionable value and that the conviction would be affirmed on the ground that it would not have raised a reasonable doubt in the minds of the jury.

87 Id.; see text at notes 20-21 supra.

$88 I d$.

89 Accord, Clarke v. Burke, 440 F.2d 853 (7th Cir. 1971), cert. denied, 404 U.S. 1039 (1972); United States v. Poole, 379 F.2d 645 (7th Cir. 1967). This standard is left undefined in Keogh. Compare United States v. Miller, 411 F.2d 825 (2d Cir. 1969) (Friendly, J.) (conviction reversed, in the absence of a request, because of "significant chance that the new evidence could have induced reasonable doubt") with United States v. Bonnano, 430 F.2d 1060 (2d Cir.), cert. denied, 400 U.S. 964 (1970) and United States ex rel. Fein v. Deegan, 410 F.2d 13 (2d Cir. 1969) (evidence held not to warrant reversal under Keogh.) 
when the prosecutor deliberately suppresses evidence, but also when he does so negligently. A standard of negligence based upon the welltrained prosecutor who is conscientiously trying to ensure the fairness of the trial must be imposed to overcome the hindsight problem and to ensure that all useful evidence is disclosed.

The standard of materiality under the Brady rule remains a difficult problem. The evidence in Brady, as in Mooney and Pyle, was of the utmost importance to the defendant. Many of the lower court cases have applied the Brady rule to the suppression of less crucial evidence, ${ }^{90}$ or have declared that the rule would be so applied. ${ }^{91}$ Attempts to articulate the materiality standard have generally come from courts reversing convictions on Brady rule grounds; their usual import is that if there is even a slight chance that a new trial would result in acquittal, the defendant's conviction must be reversed. ${ }^{22}$ This expansionist trend, however, may have suffered a severe setback because of the Supreme Court's highly restrictive approach in Moore.

\section{Rationales for Reversal and the Role of the Prosecutor}

Under the present Brady rule framework, whether evidence must be disclosed depends, not on its value to the defense insofar as this can be ascertained, but on whether an appellate court will conclude that the evidence might well have altered the verdict. The court must decide the materiality of evidence in the light of developments at a trial in which the lack of evidence may have hampered the defense in ways

90 United States v. Miller, 411 F.2d 825 (2d Cir. 1969) (although defendant possessed abundant material to impeach government's principal witness, new trial ordered for failure to reveal his pretrial hypnosis and questioning by prosecutor); Levin v. Clark, 408 F.2d 1209 (D.C. Cir. 1969) (grand larceny conviction reversed where prosecution negligently failed to reveal that bank teller did not recall changing $\$ 1,000$ bills for $\$ 20$ bills); United States v. Poole, 379 F.2d 645 (7th Cir. 1967) (prosecution gave defense incorrect name of physician who examined alleged kidnap victim for bodily harm; conviction reversed although defense never followed up the information); Ashley v. Texas, 319 F.2d 80 (5th Gir. 1963) (conviction reversed for suppressed psychiatric opinion of insanity where two other psychiatrists, one hired by defense, had already opined that defendants were quite sane); cf. People v. Hocker, 423 F.2d 960 (9th Cir. 1970) (police failure to make paraffin tests on alleged murder victim to test defendant's claim that she was a suicide did not make investigation so poor as to deny due process); Lessard v. Dickson, 394 F.2d 88 (9th Cir. 1968) (dissent would reverse for failure of prosecution to reveal that motel phone operator had said murder victim had visitor on day of crime two years before defendant's arrest).

91 United States v. Miller, 411 F.2d 825 (2d Cir. 1969), discussed note 89 supra; Hamric v. Bailey, 386 F.2d 390 (4th Cir. 1967), discussed note 81 supra; Flores v. United States, 379 F.2d 905 (5th Cir. 1967).

92 E.g., Levin v. Clark, 408 F.2d 1209 (D.C. Cir. 1969); Luna v. Beto, 395 F.2d 35 (5th Cir. 1968); Jackson v. Wainwright, 390 F.2d 288 (5th Cir. 1968); Hamric v. Bailey, 386 F.2d 390 (4th Cir. 1967). 
that are, in retrospect, difficult to conceive. Courts have so structured the disclosure requirement through their interpretation of materiality that when nondisclosure is thought to have been harmless, which often means only that the court believes the defendant guilty, the legal conclusion is that there has been no error.

This system is inherently unsatisfactory. It provides no clear standard to which the prosecutor can conform, nor does it ensure that fairness to the defendant will govern disclosure. Fairness requires that the defendant be given favorable evidence of any probative value on the questions of guilt or punishment, ${ }^{93}$ whether relevant to building a defense or to undermining the prosecutor's case. The word "material," as used in the Brady holding, should be taken to mean simply "relevant"; and whenever the prosecutor has failed to disclose relevant information to the defense, the courts should not hesitate to find error. This does not necessarily mean that a conviction need be reversed when the prosecutor has innocently overlooked truly insignificant bits of evidence. When the defendant could not have used the evidence to advantage either at or in preparation for trial, the court could find the error harmless and affirm the conviction. But this should be the unusual case. As the Supreme Court has said, "[b]efore a federal constitutional error can be held harmless, the Court must be able to declare that it was harmless beyond a reasonable doubt." 94 Thus, any slight chance that the error hampered the defense or that the evidence could have influenced the jury would be grounds for a new trial.95

In addition to fairness to the defendant, there is another, pragmatic reason for reversing convictions and remanding for retrial even when the suppressed evidence seems of minimal value and subsequent events and other evidence seem to indicate the defendant's guilt conclusively.

93 With the abolition of the death penalty in Furman v. Georgia, 408 U.S. 238 (1972), the question of punishment, actually at issue in Brady, has become less significant. The existence and imposition of the death penalty, and the reluctance of appelate courts to affirm in cases in which it has been imposed, may well have been the impetus in many cases for expansive use of the Brady rule. See, e.g., Ashley v. Texas, 319 F.2d 80 (5th Cir. 1963).

94 Chapman v. California, 386 U.S. 18, 24 (1967); cf. cases cited note 92 supra.

95 It is possible that if the present materiality standard were abandoned, courts would achieve the same result through use of the harmless error doctrine in all cases in which they would now find the evidence immaterial. There is, however, a meaningful difference that could assure some change. Harmless error is better and more tightly defined than materiality. The doctrine makes clear that the inquiry must be whether it was fair to deny the defendant the opportunity to have the evidence considered by the jury and not how that evidence would be weighed by the appellate court. The standard would be closer to that set in Hamric v. Bailey, 386 F.2d 390 (4th Cir. 1970). See note 81 supra. Courts would presumably be more reluctant to find error harmless than they have been to conclude that there was no error. 
The remand is a sanction by which to enforce the prosecutor's duty to disclose. In cases like Mooney ${ }^{96}$ and Pyle, ${ }^{97}$ convictions were reversed because of prosecutorial misconduct that shocked the conscience of the Court. In subsequent cases, the courts broadened the principle that originated in Mooney and Pyle; the ground for reversal became materiality and harm to the defendant.98 This standard has led to expansion of the prosecutor's disclosure duties. As some lower courts have expanded the meanings of "favorable" and "materiality," it has become incumbent upon the prosecutor to divulge more and more information that is less obviously crucial to the defense. Despite Moore, it is now arguably the duty of the prosecutor to be reasonably alert to defense as well as prosecution implications of all evidence he uncovers. ${ }^{90}$ There should, however, be some mechanism to enforce this duty that would not require appellate courts to attempt to make retrospective, and necessarily imperfect, evaluations of the damage after the error of nondisclosure has been committed. This could be accomplished by reversing convictions whenever the prosecutor fails to comply with the standards that the courts-and fairness-demand, regardless of the estimated likelihood that retrial would result in acquittal..$^{100}$

The manner in which the prosecutor's duty is enforced depends on the standard of duty imposed. This standard is now defined indirectly in a number of appellate court decisions that have looked to the chance, in retrospect, that disclosure would have affected the verdict. In order to ensure that prosecutors can perform their disclosure duty, it should be defined directly in terms of what kinds of evidence must be disclosed and the kinds of decisions that the prosecutor should be

96294 U.S. 103 (1995).

97317 U.S. 213 (1942).

98 Note, supra note 49.

99 Cf. Kyle v. United States, 297 F.2d 507 (2d Cir. 1961), cert. denied, 377 U.S. 909 (1964). In addition, the prosecutor must be certain that other officials make required disclosures. "The prosecutor's office is an entity and as such it is the spokesman for the government." Giglio v. United States, 405 U.S. 150, I54 (1972); United States v. Consolidated Laundries Corp., 291 F.2d 563 (2d Cir. 1961); see text at note 71 supra.

100 Even when a court might conclude that the error was harmless, there is precedent for the use of the procedure suggested here in the Supreme Court's handling of the analogous problem of illegal search and seizure. After other solutions proved unsatisfactory, the Court determined that convictions of admittedly guilty defendants must be reversed whenever they were obtained in violation of the fourth amendment. Mapp v. Ohio, 367 U.S. 643 (1961). The implicit policy decision is that some guilty men must go free in order to enforce police conformity with constitutional standards of procedure. Although the analogy is not complete, failure to disclose favorable evidence, like illegal search and seizure, is a constitutionally forbidden means of pursuing convictions. If a disclosure standard can be mandated with clarity equal to that for search and seizure, its violation should meet the same result. 
required, and allowed, to make.101 Ideally, perhaps, the defense should have access to all information in the prosecutor's file that is in any way relevant or favorable to its case. But so long as the prosecutor is required to recognize that evidence is favorable, there must be some limit to the chain of inferences he can be expected to make; nor can he be expected to research or investigate defense aspects of the case that are unrelated to the investigations he conducts for prosecution purposes.

At the same time, however, there must be limits on the extent to which the prosecutor is allowed to make decisions for the defense. If the prosecutor has or is aware of evidence that he can reasonably be expected to recognize as useful (that is, favorable) ${ }^{102}$ to the defense, he should disclose it without attempting to measure the degree to which it is relevant or favorable. Once he has recognized that evidence has defense implications, there is no reason to allow the prosecutor to fail to disclose. It should be the function of the defense, not the prosecutor, to examine the evidence and to decide what use to make of it at or in preparation for trial.

Any duty to disclose information is, of course, a departure from the prosecutor's traditional adversary role, and any expansion of that duty would require a further departure. While the specter of the destruction of the adversary system is invariably raised in opposition to any proposal for expanded criminal discovery, ${ }^{103}$ it is clear that, at least since Brady, we no longer have a purely adversary system ${ }^{104}$ and it is useful to consider the extent to which it should be preserved. The major justification of the adversary system is that, allegedly, it develops the facts better than any alternative. When it is found, however, that it impedes the development of the facts, perhaps it should be modified.

The prosecutor remains an adversary to the extent that it is his job to prove that the defendant is guilty of the crime with which he has been charged. But he is an adversary whose client is the state or federal government, and as such, his "interest in a criminal prosecution is not that it shall win a case but that justice shall be done."105 The prose-

101 See note 48 supra.

102 For further discussion of favorableness versus utility, see text at notes 108-35 infra. 103 See Louisell, Criminal Discovery: Dilemma Real or Apparent, 49 CaLIF. L. REv. 56 (1961).

104 See Fed. R. Crim. P. 16; of. Moore v. Dempsey, 261 U.S. 86 (1923); Frank v. Mangum, 237 U.S. 309 (1915).

105 Berger v. U.S., 295 U.S. 78, 88 (1935); accord, Giles v. Maryland, 386 U.S. 66, 100 (1967) (Fortas, J., concurring): "The state's pursuit is justice, not a victim." See generally Editorial Note, Discovery and Disclosure: Dual Aspects of the Prosecutor's Role in Criminal Procedure, 34 GEO. WASH. L. REv. 92 (1965). 
cutor, therefore, has two roles: first to discover the facts of the crime and then, once convinced of the defendant's guilt, to attempt to prove it to the trier of fact and to argue the position of the state as to matters of law. It is only in the latter role that the prosecutor must be an advocate. There is, however, inevitable tension between these two roles. The prosecutor's investigations will usually be designed to prepare for trial, and the prosecutor may often be convinced of the defendant's guilt long before the trial begins. ${ }^{106}$ Any attempt, therefore, to encourage the prosecutor to fulfill his duty to disclose evidence with regard to defense objectives must recognize the pressures that predispose him toward his adversary role. Perhaps the most effective means of accomplishing this is to reverse the "victory" of conviction whenever the prosecutor has neglected his duty to ensure fairness to the accused. ${ }^{107}$

\section{Why Not Open Files?}

But for the requirement of the Brady holding that the evidence be favorable to the accused, the argument for expansion would extend to disclosure of the prosecutor's entire file. Yet in light of the fairness rationale in Brady, the distinction between favorable and unfavorable evidence is, in fact, artificial. For the defendant to prepare adequately to meet the government's case against him, he must know what that case is. The chance to question even hostile witnesses before trial, and through them to seek leads to other, more favorable, witnesses could be crucial. A defendant who knows that he must confront an essentially circumstantial case may be able to concentrate on proving that the cir-

106 Prosecution is the goal towards which an investigation points: by the time the prosecutor enters the case, that goal has generally become the prosecution of a specific individual or group of individuals. While the prosecutor's stake in a trial is by no means as great as the defendant's, he may well be concerned about his professional reputation and career advancement. Moreover, it is difficult for an individual who has made the decision to prosecute, and is therefore likely to be personally convinced of the defendant's guilt, to maintain the presumption of innocence. This combination of personal and psychological factors may often make the prosecutor dismiss as unimportant evidence that he would be extremely eager to have as a defense attorney. E.g., United States v. Achtenberg, 459 F.2d-91 (8th Cir.), cert. denied, 93 S. Ct. 229 (1972), in which the prosecutor dismissed as "negative evidence" and refused to disclose eyewitnesses' statements that they had not seen the defendant participate in the crime. The conviction was reversed for this and other errors. Cf. Xydas v. United States, 445 F.2d 660 (D.C. Cir.), cert. denied, 404 U.S. 826 (1971), in which after a defense request, an in camera inspection by the court confirmed the prosecutor's denial that he had favorable evidence. When the defense discovered a possibly exculpatory statement and appealed, the conviction was affirmed on a finding that the statement would not have created reasonable doubt.

107 Contempt penalties are a possible alternative but would be unduly harsh in all but the most flagrant cases and completely inappropriate in the ordinary case of negligent nondisclosure. 
cumstances suggest an alternative explanation. Any defendant who is aware of the nature of the case against him will be better able to use his own resources to prepare his defense.

Superior preparation gives the prosecution the advantage of surprise $^{108}$ and the ability to make a smoother presentation to the jury. These tactical advantages, however intangible, are real, and difficult to justify. Like suppression, they may help "shape a trial that bears heavily on the defendant."109 Removing them would help place the parties on a more nearly equal footing in terms of preparation and thus promote the fairness of the trial.

In addition to its consistency with the constitutional rationale of $B r a d y$ and the other suppression cases, other policy considerations favor full disclosure. Open files would, of course, remove the burden on the prosecutor of attempting to determine whether evidence is favorable and allow the defense attorney to decide what evidence will help his case. ${ }^{110}$ It would thus greatly simplify the prosecutor's task of fulfilling his disclosure duty; he would have a straightforward standard to follow, known in advance, with a clear sanction for its breach. ${ }^{111}$ A rule of full disclosure would, therefore, lighten the burden that enforcement places on the courts, reducing the flood of discovery appeals that the courts have experienced under Brady.112

At the same time, it is likely that the advent of an open files requirement would not drastically change the reality of modern pretrial criminal practice. A great deal more informal discovery goes on than that required either by the Brady rule, the Federal Rules of Criminal Pro-

108 It is the innocent defendant who is most subject to being surprised by the prosecution.

109 Brady v. Maryland, 373 U.S. 83, 88 (1963).

110 See note 48 supra.

111 That some, more straightforward standard is necessary is indicated by the remarks of the former United States Attorney for Connecticut Jon Newman, Panel DisctussionDiscovery in Criminal Cases, supra note 22, at 500-01, in which he recounts having posed to a large gathering of prosecutors, experienced and inexperienced, the typical Brady hypothetical of the one eyewitness among several who states that the defendant is not the man. When Newman asked whether this should be disclosed to the defense, only two of the prosecutors said yes.

112 At the same time, however, it would be neither a foolproof check on deliberate nondisclosure nor a complete answer to negligent nondisclosure, although it would greatly ameliorate both problems. The former must be assumed to be minimal. But see Miller v. Pate, 386 U.S. 1 (1967). There could be no procedural mechanism that would prevent a determined prosecutor from falsifying or suppressing evidence or profferring perjured testimony. A requirement of open files would no doubt deter such behavior since it would make more difficult any claim of mere negligence. Negligent nondisclosure would still be possible: not every statement made to a law enforcement agent finds its way into the prosecutor's files; but it seems likely that it would be less common. 
cedure, or state standards. ${ }^{113}$ The prosecutor allows such discovery at his discretion, partially, perhaps, in recognition of his duty to inform the defense of favorable evidence, but mainly in an attempt to induce guilty pleas. In line with the present trend to encourage and protect plea bargaining, ${ }^{114}$ it would seem that the defendant should be fully informed of the case against him in order to promote intelligent choice. Under the present system, prosecutors willingly disclose their cases to defendants who are almost certain to be convicted, but the courts refuse to compel similar disclosure to defendants whose probability of acquittal is high. The equal protection problem inherent in the current practice ${ }^{115}$ would also be resolved by the suggested change to open files.

The traditional arguments against any form of expanded discovery rights for criminal defendants ${ }^{116}$ would almost certainly be raised against the proposed full disclosure requirement. Aside from the threat to the adversary system discussed above, ${ }^{117}$ there are three main objections: (1) the scales are already unbalanced in favor of the defendant; (2) the fifth amendment protection against self-incrimination makes disclosure a one-way street, which is unfair to the prosecution; and (3) disclosure would enable defendants more readily to commit perjury, tamper with documents and real evidence, and intimidate prosecution witnesses. ${ }^{118}$

Although the defense has increasingly been required to plead the defenses of insanity and alibi specially before trial, ${ }^{119}$ the basic defense advantages of avoiding self-incrimination and the beyond a reasonable doubt standard remain intact. They exist, however, as a deliberate

113 See, e.g., Brennan, J., supra note 1, at 282; Newman, Memo to all Assistant U.S. Attorneys for the District of Connecticut in L. WeINREB, Criminal Process: Cases, Com. ments and Questions 565 (1969).

114 See Santo Bello v. New York, 404 U.S. 257 (1971).

115 See Brennan, supra note 1, at 282: "Apart from the constitutional overtones of denial of equal protection involved in such a practice, I think we must all agree that the opportunity for discovery on equal terms should either be the right of all accused, or the right of none."

116 See United States v. Garsson, 291 F. 646, 649 (S.D.N.Y. 1923) (L. Hand, J.); State v. Tune, 13 N.J. 203, 98 A.2d $88 I$ (1953) (Vanderbilt, C.J.). See generally Louisell, supra note 103.

117 See text at notes 103-05 supra.

118 See United States v. Garsson, 291 F. 646, 649 (S.D.N.Y. 1928). But see Brennan, J., supra note 1 ; Goldstein, supra note 1 .

119 Brennan, J., supra note 1, at 283; Goldstein, supra note 1, at 1186; cf. Preliminary Draft of Proposed Amendments to the Federal Rules of Criminal Procedure and Federal Rules of Appellate Procedure, 52 F.R.D. 409 (1971) (rules 12.1 and 12.2 would impose these requirements in federal courts). On California's experience, see Fletcher, Pretrial Disclosure in State Criminal Cases, 12 Stan. L. Rev. 293, 315 (1960). 
common law and constitutional attempt to protect persons charged with crimes. To undermine these protections by weighting the scales against the accused in pretrial procedure as a counterbalance seems misguided. Moreover, it forces the defendant to pay a high price for the privilege of silence whether or not he exercises it.

The one-way street argument is also based on the fifth amendment protection against self-incrimination. According to this argument, defense discovery would put the prosecution at a disadvantage since the fifth amendment would prevent it from obtaining discovery against the defendant. ${ }^{120}$ In fact, however, the prosecutor's vast investigative resources, particularly his ability to use the grand jury as a tool to question witnesses before the defendant even knows he has been accused of a crime, and police interrogation, despite the Miranda rule,,$^{121}$ give him almost complete access to the defense's case. And insofar as the fifth amendment does place limitations on the prosecutor's ability to discover evidence, the response to the first argument applies.

The perjury and witness-tampering argument is more serious. It is possible that some guilty defendants with access to the prosecution's case will be better able to concoct a plausible but fraudulent defense. Even without discovery, however, the defendant can always try to get false alibi witnesses. Most authorities reject the argument of "the old hobgoblin, perjury, invariably raised with every suggested change in procedure to make easier the discovery of truth. . . ."122 The somewhat parallel experience of the civil law with expanded discovery should also serve to allay perjury fears. ${ }^{123}$

120 See State v. Tune, 13 N.J. 203, 98 A.2d 881 (1953). But see State v. Johnson, 28 N.J. 133, 145 A.2d 313 (1958), cert. denied, 368 U.S. 933 (1961). See generally Brennan, supra note 1 , at $289,292-93$.

121 Miranda v. Arizona, 384 U.S. 436 (1966).

122 Brennan, supra note 1, at 291, (also pointing out that the argument may be regarded as slander against the criminal defense bar, who, rather than defendant directly, would have access to the evidence); $6 \mathrm{~J}$. WIGMORE, EviDENGE $\$ 1863$, at 488 (9d ed. 1940), remarking that the same argument was the basis "for the one-time refusal of the criminal law ... to allow the accused to produce any witnesses at all."; cf. $4 \mathrm{~J}$. MOORE, FedERAL Practice \& 26.02(2) (3d ed. 1962).

123 See Speck, The Use of Discovery in U.S. District Courts, 60 YALE L.J. 1132, 1154 (1951): "[T] he consensus among lawyers is to reject it [the perjury argument]. This investigation disclosed the variety of ways in which lawyers use discovery to thwart perjury." Inherent in the perjury argument is an assumption directly counter to the presumption of innocence or, at least, counter to any notion that the presumption is applicable before trial. It assumes that the defendant is guilty and will therefore use his access to the prosecutor's case to avoid his just punishment. It is, of course, mainly the guilty defendant from whom we fear perjury and witness intimidation. For the presumably innocent defendant, the purpose of open files would be to point him in the right direction to gather evidence for his defense. 
Without empirical data to test the validity of the fears raised in the antidiscovery arguments, they are more appropriately directed to the need for a check on any right of the defendant to see the prosecutor's file in special cases involving unusual risks of witness intimidation. ${ }^{124}$ Rather than deny full discovery universally because of the risks it would entail in unusual cases, it seems sensible to view disclosure as a right that can be regulated, in cases of special need, by a protective order analogous to that provided in the Federal Rules of Civil Procedure. ${ }^{125}$ To obtain a protective order, the prosecutor could be required to make a particularized showing that there is reason to fear witness tampering or other abuse of discovery, which the trial judge could then weigh against the defendant's right. ${ }^{126}$

Several common law jurisdictions have greatly expanded the duty of the prosecutor to disclose evidence to the defense and, apparently, have done so successfully. Although some authorities have contended that the English experience cannot be taken as indicating the effects of criminal discovery in this country, ${ }^{127}$ the absence there of the dangers that discovery is often thought to entail at least suggests that such fears may be exaggerated. ${ }^{128}$ Similarly, although Vermont cannot be taken as a microcosm of America, the success of that state's open file system ${ }^{129}$ indicates that the risks of full disclosure may be small. Finally, there has been no evidence that the considerable expansion of the defendant's discovery rights in some states ${ }^{130}$ and in the federal courts under

124 Brennan, supra note 1, at 294-95; Goldstein, supra note 1, at 1195; Louissell, supra note 103, at 98-101. There would also be need for a work-product exception modeled after Hickman v. Taylor, 329 U.S. 495 (1947). See Note, Work Product in Criminal Discovery, 1966 WASH. U.L.Q. 321; Preliminary Draft of Proposed Amendments to Federal Rules of Criminal Procedure 48 F.R.D. 547, 590 (1970) (rule 16(a)(2)).

$125 \mathrm{FED} . \mathrm{R}$. Crv. P. 26(c).

126 For an example of such a balancing problem where disclosure of the identity of an informer was denied, with the dissent citing Brady, see United States v. Russ, 362 F.2d 843 (2d Cir. 1966).

127 State v. Tune, 13 N.J. 203, 219, 98 A.2d 881, 889 (1953).

128 See Brennan, J., supra note 1, at 284, 293, stating that Great Britain and Canada require that the defense be given notice of all evidence to be used against it at trial at the preliminary hearing. But see Louisell, supra note 103, at 66: "[T] information which the defendant might need for proper preparation of his defense which would not be disclosed to him by this machinery, either because it is withheld by the prosecutor as not admissable, or because, though admissable, it is evidence which the prosecutor does not intend to offer at trial."

129 See generally, Langrock, Vermont's Experiment in Criminal Discovery, 53 A.B.A.J. 732 (1967).

130 For discussions of California's experience in expanding discovery, see Traynor, supra note 61, and Louisell, supra note 103; cf. Comment, Discovery in California Criminal Cases: Its Importance and its Pitfalls, 38 S. CAL. L. REv. 251 (1965). 
Bradiy and the federal rules ${ }^{131}$ has led to any of the problems that have been imagined for an open file system.

The rationale that underlay Brady and the lower federal court cases that have expanded it also justifies, carried to its logical conclusion, complete disclosure of the prosecutor's file to the defendant as a matter of constitutional right. This does not mean, however, that this change can be wrought only by a court holding that due process compels it. The prosecutor's files could be opened to the defense by an act of Congress ${ }^{132}$ or by amending the Federal Rules of Criminal Procedure. ${ }^{133}$ Since it relates directly to the trial function, discovery should probably remain in the hands of courts, which will have to deal on a case-by-case basis with whatever problems may arise. ${ }^{134}$ Effecting the change by amending the federal rules would allow relatively easy resolution of whatever problems result by means of further amendment. Universal application of an open file requirement in both state and federal courts, however, could only be achieved by a Supreme Court decision that due process compels full disclosure.

In light of the Court's action in Moore, ${ }^{135}$ such a decision seems unlikely. Nonetheless, full disclosure is both desirable and consistent with the fair trial rationale of $B r a d y$. It could logically be wrought through Supreme Court extension of lower court case law under Brady and of the principles of that case.

Victor Bass

131 Fed. R. CRIM. P. 16, 17(c).

132 Cf. 18 U.S.C. $\$ 3500$ (1970) (Jencks Act).

133 Cf. Preliminary Draft of Proposed Amendments to Federal Rules of Criminal Procedure, stspra note 124, at 587 (rule 16).

134 See Brennan, supra note 1, at 293-94.

135 Moore v. Illinois, 408 U.S. 786 (1972); see text at notes 73-78 stupra. 